\title{
Influence of thrombophilic genes; MTHFR (C677T), FVL (GI69|A) and ACE (I28005D) in pregnant women with pre-eclampsia
}

\begin{abstract}
Objective: Pre-eclampsia (PE) is a pregnancy complication and vascular disorder recognized by new onset gestational hypertension and proteinuria. It may lack of immunological mother and fetus signalization. The exact pathogenesis of PE remains uncertain. The aim of this study was to identify the selected polymorphisms in the genesis of PE.

Methods: PE was identified in the second half of pregnancy, often in the latter part of the second or final trimesters, although it may occur earlier. This is a case-control study carried out in 105 cases and 100 ages matched normal pregnant women (controls). We have selected three different genes: MTHFR, FVL, ACE to evaluate mutation/ polymorphisms in $677 \mathrm{C}>\mathrm{T}, 1691 \mathrm{G}>\mathrm{A}$ and $\mathrm{I}>\mathrm{D} 28005$ genotypes by PCR followed by Restriction fragment length polymorphism and gel electrophoresis.

Results: Statistical analysis was performed by Openepi software. Both the allele and genotype frequencies between PE cases and controls were contradictory and odds ratio with $95 \%$ confidence interval did not reveal statistical significant in either alleles or genotypes of any of the three snips. MDR analysis also failed to show the disease marker association in the PE women. It has found an interaction between MTHFR and FVL. These findings suggest the existence of population based differences in the association of candidate gene variants with PE emphasizes the importance of studying specific polymorphisms, which can be used as biomarkers uniquely for an ethnic group.
\end{abstract}

Conclusions: In conclusion, the present case-control study in pregnant women appears as lack of association with the selected polymorphisms in the study population.

Keywords: preeclampsia, pregnancy induced hypertension, methylene tetrahydro folate reductase, factor $\mathrm{V}$ leiden, angiotensin converting enzyme
Volume 2 Issue I - 2015

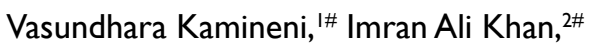 \\ Kiran Kumar Vattam, ${ }^{3}$ Subhadra Poornima, ${ }^{3}$ \\ Qurratulain Hasan ${ }^{3,4}$ \\ 'Department of Obstetrics and Gynecology, Kamineni Hospitals, \\ India \\ ${ }^{2}$ Department of Clinical Laboratory Sciences, King Saud \\ University, Kingdom of Saudi Arabia \\ ${ }^{3}$ Department of Genetics and Molecular Medicine, Kamineni \\ Hospitals, India \\ ${ }^{4}$ Department of Genetics, Vasavi Medical and Research Centre, \\ India \\ \#Indicates equal contribution
}

Correspondence: Qurratulain Hasan, Department of Genetics and Molecular Medicine, Kamineni Hospitals, Hyderabad500068, India, Tel 009140-39879999, Extn 210, Fax 00914024022277,Email qhasan2000@yahoo.com

Received: November 3, 2014 | Published: February 03, 2015
Abbreviations: PE, pre eclampsia; PIH, pregnancy induced hypertension; E, eclampsia; FVL, factor V leiden; APC, activated protein $\mathrm{C}$; I/D, insertion-deletion; PCR, polymerase chain reaction; Ors, odds ratio; HWE, hardy-weinberg equilibrium; ACE, angiotensin converting enzyme; $M T H F R$, methylene tetrahydro folate reductase; MDR, multifactor dimensionality reduction

\section{Introduction}

Preeclampsia (PE) is a hypertensive disorder associated with elevated blood pressure and proteinuria frequently develops after 20 weeks of gestation. ${ }^{1}$ Pregnancy Induced Hypertension (PIH) was defined as persistently raised blood pressure $(\geq 140 / 90 \mathrm{mmHg})$ starting after the $20^{\text {th }}$ week of gestation in an otherwise normotensive woman with proteinuria $(\geq 300 \mathrm{mg} / 24 \mathrm{~h}){ }^{2}$ The incidence of PIH in India is $7-10 \%$ of all antenatal admissions. ${ }^{3}$ It can progress to PE or eclampsia (E) which are life threatening conditions leading to both maternal and perinatal morbidity and mortality. The pathophysiology of PE is still unclear; however, studies have demonstrated an association with a cluster of metabolic abnormalities such as dyslipidemia and hyper-insulinaemia. ${ }^{4}$ Toxemia in pregnancy which includes PE and $\mathrm{E}$ contributes to $12 \%$ of maternal deaths in India. The general risk factors associated with PE are advanced maternal age, history of PE, obesity, multiple pregnancies and women with diabetes/ gestational diabetes.

Genetic polymorphisms are markers of biologic diversity and genotypic variations, which correlate with specific phenotypes are sometimes associated with the development of human disease in different ethnic groups. ${ }^{5}$ Polymorphisms of various genes encoding thrombophilic factors like Methylenetetrahydrofolate reductase (MTHFR; OMIM: 607093), Factor V Leiden (FVL; OMIM) and Angiotensin converting enzyme ( $A C E$-OMIM) have been evaluated in numerous studies to assess their association with several complex disorders. MTHFR is a critical folate-metabolizing enzyme which requires riboflavin as its co-factor. ${ }^{6}$ The 5,10 -MTHFR enzyme catalyzes the conversion of 5,10 -methylenetetrahydrofolate to 5 -methyltetrahydrofolate, the primary circulatory form of folate, and a cosubstrate for homocysteine remethylation to methionine. ${ }^{7}$ The thermolabile variant occurs at $677^{\text {th }}$ position substitutes from C-T and this variant involves an exchange of a valine for an alanine residue at amino acid position 226 of the MTHFR enzyme. $^{8} \mathrm{G} 1691$ is a common mutation in the $F V L$ gene involving a substitution from guanine to adenine at amino acid position 506, which results in a defective 
FVL protein unable to react with activated protein C (APC), has been previously associated with increased coagulation activity and susceptibility to thromboembolism. ${ }^{9}$

$A C E$ is a zinc metallopeptidase widely distributed on the surface of endothelial and epithelial cells, which plays an important role in reninangiotensin system cascade by converting angiotensin I to angiotensin II. ${ }^{10}$ One of these polymorphisms is an insertion-deletion (I/D) of the 287-bp Alurepetitive element in intron 16 of the gene located on chromosome 17, has been identified and this polymorphism does not affect the protein structure but influences expression of this gene. ${ }^{11}$ The D-allele is associated with higher concentrations of ACE compared with the I-allele. The DD genotype was found to be a genetic marker associated with human hypertension. ${ }^{12}$ The aim of this present study was to investigate the distribution of allele and genotype frequencies of the C677T, G1691A and I28005D mutation/polymorphisms with $\mathrm{PE}$ in south Indian population.

\section{Methods}

\section{Ethics}

The study was approved by Ethics committee of the Kaminen Hospitals, Hyderabad, India. Written informed consent was obtained from all the pregnant women who have participated in this study.

\section{Selection of pregnant women}

In order to evaluate the allele and genotype frequencies of selected polymorphisms in the south Indian population we carried out a hospital based case-control study during the period (January 2006- December 2009). The sample consists of 205 pregnant women; 105 of them were diagnosed with PE and acted as a "study group" while the other 100 pregnant women were normal and acted as a "control group". All the subjects belonged to the same geographic region. PE was diagnosed based on two consecutive measurements of systolic and diastolic blood pressure taken, after the 20th week of pregnancy, at least 6 hours apart. Increase in diastolic blood pressure to $>110 \mathrm{mmHg}$ or a rise of $15-30 \mathrm{mmHg}$ above the normal pre-pregnancy values indicates $\mathrm{PE}$ (Figure 1). This could be accompanied with $300 \mathrm{mg}$ protein in the 24 hour urine specimen or urine dipstick $>1+.4,13$ The women with normal systolic and diastolic blood pressure and absence of proteinuria were considered as controls. Edema was established with an increase of $500 \mathrm{~g}$ in weight during a week or clinically defined by facial, hand or generalized swelling. Eclampsia was defined as preeclampsia associated with convulsive syndrome or coma. The exclusion criteria were pregnant women with chronic hypertension.

\section{Sampling}

Two milliliter of peripheral blood was collected in the EDTA vacutainer from all the pregnant women. Instantly after collection, whole blood was sent to the Department of Genetics and Molecular medicine for isolation of DNA.

\section{DNA extraction and genotyping}

Salting out technique was used to extract the DNA from peripheral blood leucocytes as routinely used in our lab. ${ }^{14} A C E$ I28005D (rs 4646994) polymorphism was detected by Polymerase chain reaction (PCR) (Applied Biosystems), amplification and gel electrophoresis, while C677T (rs 1801133) and FVL (G1691A) variants were studied by PCR amplification followed by Restriction Fragment Length Polymorphism (RFLP) and agarose gel electrophoresis. ${ }^{10,15}$ The details of primers, annealing temperatures, fragment sizes and restriction enzymes used in this study are tabulated in Table $1 \&$ Table 2. PCR products for $\mathrm{C} 677 \mathrm{~T}$ and $\mathrm{G} 1691 \mathrm{~A}$ variants are digested at $37^{\circ} \mathrm{C}$, after electrophoresis, the digested products were visualized on $2 \%$ agarose gel with ethidium bromide staining.

\section{Pregnant women \\ $n=205$}

(All the subjects belonged to the same geographic region)
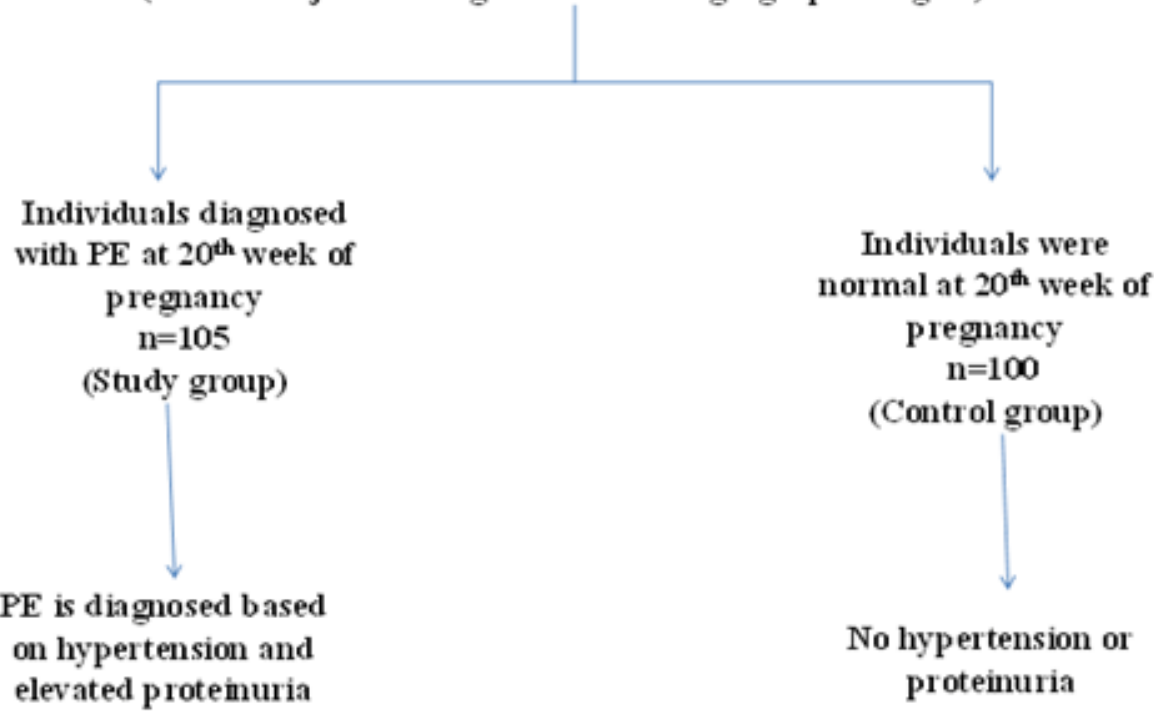

Figure I Patient selection criteria. 
Table I Selection of genes (SNPs) and primers involved in this study

\begin{tabular}{|c|c|c|c|c|c|c|c|}
\hline Gene & SNP & rs no & $\begin{array}{l}\text { Nucleotide } \\
\text { change }\end{array}$ & $\begin{array}{l}\text { Amino } \\
\text { acid } \\
\text { change }\end{array}$ & Forward primer & Reverse primer & Fragment \\
\hline MTHFR & EXON 5 & rsI80II33 & $\mathrm{C}>\mathrm{TI}$ & Ala-Val & $\begin{array}{l}\text { TGAAGGAGA } \\
\text { AGGTGTCTGCGGGA }\end{array}$ & $\begin{array}{l}\text { GGACGGTGCG } \\
\text { GTGAGAGTG }\end{array}$ & $198 \mathrm{bp}$ \\
\hline $\begin{array}{l}\text { FACTOR } \\
V\end{array}$ & EXON 10 & rs6020 & $\mathrm{G}>\mathrm{Al}$ & $\begin{array}{l}\text { Gua- } \\
\text { Ade }\end{array}$ & $\begin{array}{l}\text { TCAGGCAGGAA } \\
\text { CAACACCAT }\end{array}$ & $\begin{array}{l}\text { GGTTACTTCAAGGAC } \\
\text { AAAATACCTGTAAAGCT }\end{array}$ & $24 \mathrm{Ibp}$ \\
\hline $\mathrm{ACE}$ & $\begin{array}{l}\text { INTRON } \\
16\end{array}$ & rs 4646994 & $|>D|$ & - & $\begin{array}{l}\text { CTGGAGACCACT } \\
\text { СССАTССTTTCT }\end{array}$ & $\begin{array}{l}\text { GATGTGGCCATCAC } \\
\text { ATTCGTCACGAT }\end{array}$ & $490 \mathrm{bp}$ \\
\hline
\end{tabular}

'Risk allele

Table 2 Reaction conditions for PCR-RFLP of C677T and GI69IA polymorphisms

\begin{tabular}{|c|c|c|c|c|c|c|}
\hline Gene & Band & Amino acid variation & Enzyme & Digestion & Temperature & Sizes (bp) \\
\hline MTHFR & Ip36.22 & $\mathrm{C} 677 \mathrm{~T}$ & Hinfl & $2 \mathrm{~h}$ & $37^{\circ} \mathrm{C}$ & $\begin{array}{l}\text { C: 198bp } \\
\text { T:I75/23bp }\end{array}$ \\
\hline FACTOR V & I q24.2 & GI69IA & HIndIII & $16 \mathrm{~h}$ & $37^{\circ} \mathrm{C}$ & $\begin{array}{l}\text { G: } 241 \text { bp } \\
\text { A: } 209 / 32 b p\end{array}$ \\
\hline ACE & $17 q 23$ & - & - & - & - & $\begin{array}{l}\text { I: 490bp } \\
\text { D: 190bp }\end{array}$ \\
\hline
\end{tabular}

\section{Statistical analysis}

We used Openepi software system (Openepi, version 2.3.1, Atlanta, GA, USA) to perform all the statistical analysis. Allele and genotype frequency differences between the cases and controls were tested for each SNP using a chi-square test. Odds ratio (ORs) and $95 \%$ confidence intervals are calculated to estimate the strength of the association between polymorphism genotype alleles in pregnancy women by binomial logistic regression. Independent sample $t$-test was used to test the cases and controls. Yates correction was also performed. Clinical data are expressed as mean \pm standard deviation $(\mathrm{M} \pm \mathrm{SD})$. A $p$ value less than $0.05(p<0.05)$ was used as the criterion of significance. Pearson's Chi-square $\left(\chi^{2}\right)$ or Fischer's exact two test (two-sided) was used to test the deviations of genotype distribution from Hardy-Weinberg equilibrium (HWE) and to determine the allele and genotype frequencies. Gene-gene interaction was performed by multifactor dimensionality reduction (MDR) analysis software (Linux version).

\section{Results}

Clinical data of the pregnant women with and without PE are listed in Table 3. The mean age in the study group ( $28.9 \pm 4.5$ years) and mean period of gestation $(24.9 \pm 5.0)$ at the time of recruitment in the study was comparable with the control group $(26.9 \pm 4.3$ years) and $24.1 \pm 4.9$ weeks, respectively. The BMI of the pregnant women as well as SBP and DBP were significantly different between the two groups $(p<0.05)$.

\section{Amino acids substitution analysis}

Amino acid changes at position 677 and 1691 in the exon 5 and
10 regions of $M T H F R$ and $F V L$, respectively, were investigated using PCR-RFLP. Distribution of genotype frequencies of the C677T MTHFR polymorphisms in controls satisfies the HWE. The genotype frequencies of MTHFRin cases are $78.1 \% \mathrm{CC}, 19 \% \mathrm{CT}$ and $2.9 \%$ TT respectively, whereas in the control group the homozygous CC, variants $\mathrm{TT}$ and heterozygous $\mathrm{CT}$ genotypes are found at frequencies of $82 \%, 17 \%$ and $1 \%$, respectively. The allele frequencies observed in the cases are $0.88(\mathrm{C})$ and $0.12(\mathrm{~T})$ and in controls $0.90(\mathrm{C})$ and $0.10(\mathrm{~T})$. The genotypes and allele frequencies of C677T were not statistically different between the cases and controls nor were they associated with $\mathrm{PE}(\mathrm{OR}-1.27,95 \% \mathrm{CI}=0.64-2.54 ; p=0.48)$. Similarly, the frequency of Factor V Leiden mutation G1691A was seen in $2.9 \%$ of the PE cases and none of the controls (Table 4) \& (Table 5).

\section{Insertion/deletion polymorphism analysis}

The frequencies of $A C E \mathrm{I}$ and $\mathrm{D}$ alleles were 0.56 and 0.43 in the cases and 0.49 and 0.50 in the controls. The genotype and allele distribution of I28005D polymorphisms are summarized in Table 4 \& Table 5. Distribution of genotypes and allele frequencies of I28005D polymorphism in cases and controls are satisfied by the HWE. The genotype frequencies for I28005D polymorphisms were not significantly different between cases and controls. The results from this study show a high prevalence of DD genotype in the controls (31\%) when compared to the PE women $(24.8 \%)$.

\section{MDR analysis}

Gene-gene interaction was performed by MDR analysis to explore the pathogenesis of PE women. MDR analysis was carried out between three genes and the interaction appears to be between MTHFR and Factor V Leiden (Figure 2). 
Table 3 Clinical Data for PE cases and controls involved in this study

\begin{tabular}{llll}
\hline & PE $(\mathbf{n}=105)$ & Controls $(\mathbf{n}=100)$ & p value \\
\hline Age (Years) & $28.9 \pm 4.5$ & $26.9 \pm 4.3$ & $\mathrm{p}=0.64$ \\
BMI $\left(\mathrm{Kg} / \mathrm{m}^{2}\right)$ & $27.1 \pm 3.9$ & $26.2 \pm 3.7$ & $\mathrm{p}=0.59$ \\
Gestational age & $24.1 \pm 4.9$ & $24.9 \pm 5.0$ & $\mathrm{p}=0.84$ \\
SBP $(\mathrm{mmHg})$ & 158 & 119 & $\mathrm{p}=0.0001$ \\
DBP $(\mathrm{mmHg})$ & $10 \mathrm{I}$ & 79 & $\mathrm{P}=0.000 \mathrm{I}$ \\
\hline
\end{tabular}

Table 4 Genotype distribution of 677 C > T, I69IG >A, and 28005 I DD polymorphisms in the pregnancy women enrolled in the study

\begin{tabular}{|c|c|c|c|c|c|}
\hline Genotypes & PE $(n=\mid 05)$ & Controls $(n=100)$ & Odds ratio $(95 \% \mathrm{CI})$ & $\chi^{2}$ & p value \\
\hline \multicolumn{6}{|l|}{$677 C>T$} \\
\hline $\mathrm{CC}$ & $82(78.1)$ & $82(82)$ & Reference & & \\
\hline CT & $20(19.0)$ & $17(17)$ & I.I7 $(0.57,2.4)$ & 0.6567 & 0.6559 \\
\hline TT & $03(2.9)$ & $0 \mathrm{I}(\mathrm{I})$ & $3(0.30,29.44)$ & 0.3246 & 0.3231 \\
\hline \multicolumn{6}{|l|}{$|69| G>A$} \\
\hline GG & 102 (97.1\%) & $100(100 \%)$ & Reference & & \\
\hline GA & $3(2.9 \%)$ & $0(0 \%)$ & $6.8(0.3,135.2)$ & 0.1423 & $0.1414^{*}$ \\
\hline AA & $0(0 \%)$ & $0(0 \%)$ & $0.03(0.0005,1.9)$ & 0.015 & $0.014^{*}$ \\
\hline \multicolumn{6}{|l|}{ ACE I>D } \\
\hline II & $39(37.1)$ & $30(30)$ & Reference & & \\
\hline ID & $40(38.1)$ & $39(39)$ & $0.78(0.4,1.5)$ & 0.4752 & 0.4737 \\
\hline DD & $26(24.8)$ & $3 I(3 I)$ & $0.64(0.3, I .3)$ & 0.225 & 0.2232 \\
\hline
\end{tabular}

*indicates Yates correction

Table 5 Allele distribution of 677 C $>$ T, I69IG $>$ A, and 28005 I DD polymorphisms in the pregnancy women enrolled in the study

\begin{tabular}{|c|c|c|c|c|c|}
\hline Alleles & $\operatorname{PE}(n=105)$ & Controls $(n=100)$ & Odds ratio $(95 \% \mathrm{CI})$ & $\chi^{2}$ & p value \\
\hline \multicolumn{6}{|c|}{$677 \mathrm{C}>\mathrm{T}$} \\
\hline $\mathrm{C}$ & $184(0.88)$ & $181(0.90)$ & Reference & & \\
\hline $\mathrm{T}$ & $26(0.12)$ & $19(0.10)$ & $1.34(0.71,2.51)$ & 0.3515 & 0.3509 \\
\hline \multicolumn{6}{|c|}{$1691 G>A$} \\
\hline G & $207(0.99)$ & $200(100)$ & Reference & & \\
\hline A & $3(0.1)$ & $0(0)$ & $6.76(0.34,131.8)$ & 0.1452 & $0.1446^{*}$ \\
\hline \multicolumn{6}{|c|}{ ACE I $>$ D } \\
\hline I & $118(0.56)$ & $99(0.495)$ & Reference & & \\
\hline $\mathrm{D}$ & $92(0.44)$ & $101(0.505)$ & $0.76(0.51,1.12)$ & 0.1756 & 0.1751 \\
\hline
\end{tabular}

*indicates Yates correction 


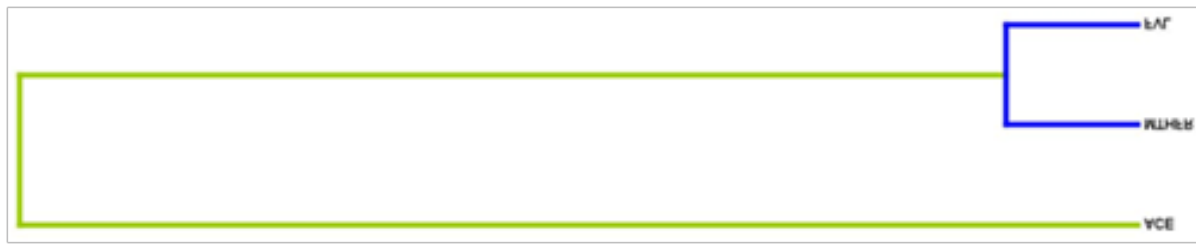

Figure 2 Dendogram representation of interaction of MTHFR, FVL and ACE genes by MDR analysis.

\section{Discussion}

In this prospective case-control study, we scrutinized the association of three common and widely studied mutation/ polymorphisms of MTHFR (677 C > T), Factor V Leiden (1691G $>$ A) and $A C E(28005 \mathrm{I}>\mathrm{D})$ genes with PE cases and control subjects in south Indian population. PE has been associated with insufficient trophoblast invasion of maternal spiral arteries, impaired placental perfusion, and widespread endothelial cell dysfunction. ${ }^{16}$ The causes leading to these pathological alterations remain unclear. PE is believed to be a multifactorial disorder with a strong genetic component. ${ }^{17}$ The incidence of PE is three times higher in women with a family history of the disease ${ }^{18}$ nearly two and a half times more common in daughters of women with PE than in their daughters-in-law; ${ }^{19}$ twice as frequent in pregnancies fathered by men who are themselves the product of pregnancies complicated by PE compared with pregnancies fathered by men who were born of normotensive pregnancies. ${ }^{18}$

$\mathrm{PE}$ is a significant obstetric problem in India, however, the contribution of genetic polymorphisms to PE have not been well studied. Some papers have looked at the role of eNOS (Glu298Asp), FOXp3 $(-3279 \mathrm{C}>\mathrm{A})$ and thrombophilic $(M T H F R+F V L+A C E)$ gene polymorphisms ${ }^{13,20,21}$ in PE. The prevalence of two thrombophilic gene polymorphisms in our study are similar to previously reported figures for MTHFR and FVLin the North Indian population..$^{22}$ The Factor V Leiden mutation was seen in 3 cases in this population. MTHFR 677 $\mathrm{T}$ allele was found to be heterozygous in $21 \%$ and homozygous TT in $3 \%$ of cases despite the fact that these percentages are higher than the controls the values are not statistically significant. This may be because the women with MTHFR CT or TT genotype in the control group may be those who have adequate folic acid in their diet or have received folic acid supplementation and hence do not show symptoms of PE. The result indicates that MTHFR, FVL and $A C E$ variants were not significantly associated. Our results are not similar to those of Agarrwal et al. ${ }^{13}$ which suggested that ACE polymorphism has a protective effect. A recent meta-analysis has shown that MTHFR is significantly increases the risk in PE in Caucasian and East Asian population. $^{23}$

In our study $A C E$ I28005D polymorphism has no role in PE either in allele or genotype frequencies and this was supported by earlier studies. ${ }^{24-27}$ On the other hand, few studies have addressed the positive association with higher incidence of DD genotype and/or D allele in $\mathrm{PE}$ and/or PIH. ${ }^{28-32}$ One of the possible reasons for the inconsistency among these reports may be a genetic basis that causes different susceptibilities among different populations. ${ }^{33}$ Table 6 represents the earlier studies with their association. This study has not found any association in the $A C E \mathrm{I} 28005 \mathrm{D}$ polymorphism with $\mathrm{PE}$ in the population studied, although $\mathrm{D}$ allele of $A C E$ is found to be higher in controls $(50.5 \%)$. A previous study from Indian population had evaluated the association of $A C E I 28005 \mathrm{D} .{ }^{32}$ The other possibility may be that DD genotype plays a permissive role in the development of $\mathrm{PE}$ in those individuals who are at the development of PE/PIH due to other factors. We have excluded the women who are predisposing to the development of PIH, chronic hypertension, collagen disorders, diabetes and multiple pregnancies.

Table 6 Earlier studies involved in the ACE gene with PE/control subjects

\begin{tabular}{|c|c|c|c|c|}
\hline Prior studies & Country & PE & Controls & Association \\
\hline Agarrwal et al. ${ }^{13}$ & India & 120 & 118 & No \\
\hline Agarrwal et al. ${ }^{22}$ & India & 200 & 200 & No \\
\hline Morgan et al..$^{24}$ & Europe & 72 & 83 & Yes \\
\hline Galao et al..$^{25}$ & Brazil & 51 & 71 & No \\
\hline Kobashi et al. ${ }^{26}$ & Japan & 122 & 291 & No \\
\hline Mando et al. ${ }^{28}$ & Italy & 197 & 410 & No \\
\hline Gurdol et al. ${ }^{29}$ & Turkey & 95 & 89 & No \\
\hline Mello et al. ${ }^{30}$ & Italy & 17 & 58 & Yes \\
\hline Choi et al. ${ }^{31}$ & Korea & 90 & 98 & Yes \\
\hline Kaur et al. ${ }^{32}$ & India & 50 & 50 & No \\
\hline Bereketoglu et al. ${ }^{33}$ & Turkey & 120 & 116 & Yes \\
\hline Heiskanen et al. ${ }^{37}$ & Finland & 133 & 115 & Yes \\
\hline Bouba et al..$^{38}$ & Greece & 41 & 102 & Yes \\
\hline Roberts et al. ${ }^{39}$ & $\begin{array}{l}\text { South } \\
\text { Africa }\end{array}$ & 271 & 338 & No \\
\hline Kim et al. ${ }^{40}$ & Korean & 94 & 105 & No \\
\hline El Shafie et al. ${ }^{4 l}$ & Egypt & 117 & 102 & No \\
\hline Velloso et al. ${ }^{42}$ & Brazil & 20 & 20 & Yes \\
\hline Miskovic et al. ${ }^{43}$ & Croatia & 60 & 50 & Yes \\
\hline Procopciuc et al..$^{44}$ & Romania & 36 & 71 & No \\
\hline Salimi et al..$^{45}$ & Iran & 125 & 132 & Yes \\
\hline Serrano et al..$^{46}$ & Columbia & 665 & 1046 & No \\
\hline Pfab et al. ${ }^{47}$ & Germany & 1068 & - & - \\
\hline Benedetto et al. ${ }^{.8}$ & Italy & 120 & 108 & Yes \\
\hline Present study & India & 105 & 100 & No \\
\hline
\end{tabular}


MDR analysis is used for detecting and characterizing gene-gene and gene-environment interaction effects on risk of common complex multifactorial diseases in case-control and discordant-sib-pair studies with relatively small samples. ${ }^{34}$ MDR is nonparametric in both statistical and genetic sense, balances accurately as the evaluation to measure the potential risks. ${ }^{35}$ We performed the MDR analysis using the three genes in combination to analyze the risk of the disease. It revealed only an interaction between MTHFR and FVL genotypes have showed an association in combination of genes, but turns to be protective for the PE. In conclusion, the results of the present study suggest no relation between PE susceptibility and MTHFR (C677T), $F V L(\mathrm{G} 1691 \mathrm{~A}), A C E(\mathrm{I} 28005 \mathrm{D})$ gene polymorphisms in the examined south Indian population.

\section{Acknowledgments}

This study was supported by Kamineni hospitals, Hyderabad, India. Gratitude is expressed to all the volunteers who have participated in this study.

\section{Authors contribution}

$\mathrm{KV}$ is a gynecological clinician, selected and recruited the cases and controls. KIA has prepared the manuscript, helped in the interpretation of the data and executed the statistics. VKK and PS has performed the genotyping and analyzed the data. HQ was head of the project, planned the experiment, and revised the draft. All the author's approved the final version of manuscript.

\section{Conflicts of interest}

The authors declare there is no conflict of interests.

\section{References}

1. Yelumalai S, Muniandy S, Zawiah Omar S, et al. Pregnancy-induced hypertension and preeclampsia: levels of angiogenic factors in Malaysian women. J Clin Biochem Nutr. 2010;47(3):191-197.

2. Brosens IA, De Sutter P, Hamerlynck T, et al. Endometriosis is associated with a decreased risk of pre-eclampsia. Hum Reprod. 2007;22(6):17251729 .

3. Kumar L, Chaurasiya OS, Jian G, et al. The Evaluation of Cord Blood Magnesium Level in Neonates of Magnesium Sulphate Treated Preeclamptic/eclamptic Mothers and its Clinical Correlation. People's Journal of Scientific Research. 2013;6(1):16-19.

4. Irinyenikan TA, Roberts OA, Arowojolu A. Serum lipid levels in pregnant normotensive and gestational hypertensive women in Ibadan, Nigeria. Annals of Biological Research. 2013;4(4):204-208.

5. Bhaskar S, Ganesan M, Chandak GR, et al. Association of PON1 and APOA5 gene polymorphisms in a cohort of Indian patients having coronary artery disease with and without type 2 diabetes. Genet Test Mol Biomarkers. 2011;15(7-8):507-512.

6. Ueland PM, Hustad S, Schneede J, et al. Biological and clinical implications of the MTHFR C677T polymorphism. Trends Pharmacol Sci. 2001;22(4):195-201.

7. Hickey SE, Curry CJ, Toriello HV. ACMG Practice Guideline: lack of evidence for MTHFR polymorphism testing. Genet Med. 2013;15(2):153156.

8. Gupta SK, Kotwal J, Kotwal A, et al. Role of homocysteine \& amp; MTHFR C677T gene polymorphism as risk factors for coronary artery disease in young Indians. Indian J Med Res. 2012;135(4):506-512.
9. Rahimi Z, Hasanvand A, Felehgari V. Interaction of MTHFR 1298C with ACE D allele augments the risk of diabetic nephropathy in Western Iran. DNA Cell Biol. 2012;31(4):553-559.

10. Khan IA, Jahan P, Hasan Q, et al. Angiotensin-converting enzyme gene insertion/deletion polymorphism studies in Asian Indian pregnant women biochemically identifies gestational diabetes mellitus. J Renin Angiotensin Aldosterone Syst. 2014;14(4):566-571.

11. Reshetnikov EA, Akulova LY, Dobrodomova IS, et al. The insertiondeletion polymorphism of the ACE gene is associated with increased blood pressure in women at the end of pregnancy. $J$ Renin Angiotensin Aldosterone Syst. 2013.

12. du Cheyron D, Fradin S, Ramakers M, et al. Angiotensin converting enzyme insertion/deletion genetic polymorphism: its impact on renal function in critically ill patients. Crit Care Med. 2008;36(12):3178-3183.

13. Aggarwal S, Dimri N, Tandon I, et al. Preeclampsia in North Indian women: the contribution of genetic polymorphisms. J Obstet Gynaecol Res. 2011;37(10):1335-1341.

14. Khan IA, Shaik NA, Pasupuleti N, et al. Screening of mitochondrial mutations and insertion-deletion polymorphisms in gestational diabetes mellitus in Asian Indian women. Saudi J Bio Sci. 2015.

15. Parveen F, Shukla A, Agrawal S. Should factor V Leiden mutation and prothrombin gene polymorphism testing be done in women with recurrent miscarriage from North India? Arch Gynecol Obstet. 2013;287(2):375381.

16. Chen X, Gan T, Liao Z, et al. Foxp3 (-/ATT) polymorphism contributes to the susceptibility of preeclampsia. PLoS One. 2013;8(4):e59696.

17. Lin R, Lei Y, Yuan Z, et al. Angiotensinogen gene M235T and T174M polymorphisms and susceptibility of pre-eclampsia: a meta-analysis. Ann Hum Genet. 2012;76(5):377-386.

18. Esplin MS, Fausett MB, Fraser A, et al. Paternal and maternal components of the predisposition to preeclampsia. New England Journal of Medicine. 2001;344(12):867-872.

19. Arngrimsson R, Bjornsson S, Geirsson RT, et al. Genetic and familial predisposition to eclampsia and pre-eclampsia in a defined population. $\mathrm{Br}$ J Obstet Gynaecol. 1990;97(9):762-769.

20. Sharma D, Trivedi SS, Bhattacharjee J. Oxidative stress and eNOS (Glu298Asp) gene polymorphism in preeclampsia in Indian population. Mol Cell Biochem. 2011;353(1-2):189-193.

21. Jahan P, Sreenivasagari R, Goudi D, et al. Role of Foxp3 gene in maternal susceptibility to pre-eclampsia - a study from South India. Scand J Immunol. 2013;77(2):104-108.

22. Aggarwal PK, Jain V, Jha V. Endothelial nitric oxide synthase, angiotensin converting enzyme and angiotensinogen gene polymorphisms in hypertensive disorders of pregnancy. Hypertens Res. 2010;33(5):473-477.

23. Wang XM, Wu HY, Qiu XJ. Methylenetetrahydrofolate reductase (MTHFR) gene C677T polymorphism and risk of preeclampsia: an updated meta-analysis based on 51 studies. Arch Med Res. 2013;44(3):159-168.

24. Morgan L, Foster F, Hayman R, et al. Angiotensin-converting enzyme insertion - deletion polymorphism in normotensive and pre-eclamptic pregnancies. J Hypertens. 1999;17(6):765-768.

25. Galao AO, de Souza LH, da Costa BE, et al. Angiotensin-converting enzyme gene polymorphism in preeclampsia and normal pregnancy. $A m$ Obstet Gynecol. 2004;191(3):821-824.

26. Kobashi G, Hata A, Shido K, et al. Insertion/deletion polymorphism of the angiotensin-converting enzyme gene and preeclampsia in Japanese patients. Semin Thromb Hemost. 2005;31(3):346-350. 
27. Tamura T, Johanning GL, Goldenberg RL, et al. Effect of angiotensinconverting enzyme gene polymorphism on pregnancy outcome, enzyme activity, and zinc concentration. Obstet Gynecol. 1996;88(4 Pt 1):497502 .

28. Mando C, Antonazzo P, Tabano S, et al. Angiotensin-converting enzyme and adducin-1 polymorphisms in women with preeclampsia and gestational hypertension. Reprod Sci. 2009;16(9):819-826.

29. Gurdol F, Isbilen E, Yilmaz H, et al. The association between preeclampsia and angiotensin-converting enzyme insertion/deletion polymorphism. Clin Chim Acta. 2004;341(1-2):127-131.

30. Mello G, Parretti E, Gensini F, et al. Maternal-fetal flow, negative events, and preeclampsia: role of ACE I/D polymorphism. Hypertension. 2003;41(4):932-937.

31. Choi H, Kang JY, Yoon HS, et al. Association of Angiotensin-converting enzyme and angiotensinogen gene polymorphisms with preeclampsia. $J$ Korean Med Sci. 2004;19(2):253-257.

32. Kaur R, Jain V, Khuller M, et al. Association of angiotensin-converting enzyme gene polymorphism with pregnancy-induced hypertension. Acta Obstet Gynecol Scand. 2005;84(10):929-933.

33. Bereketoglu C, Kasap M, Pazarbası A. Studies on angiotensin-converting enzyme insertion/deletion polymorphism and genotype distributions in Turkish preeclampsia patients. J Pregnancy. 2012.

34. Hahn LW, Ritchie MD, Moore JH. Multifactor dimensionality reduction software for detecting gene-gene and gene-environment interactions. Bioinformatics. 2003;19(3):376-382.

35. Ritchie MD, Hahn LW, Roodi N, et al. Multifactor-dimensionality reduction reveals high-order interactions among estrogen-metabolism genes in sporadic breast cancer. Am J Hum Genet. 2001;69(1):138-147.

36. Ritchie MD, Hahn LW, Moore JH. Power of multifactor dimensionality reduction for detecting gene-gene interactions in the presence of genotyping error, missing data, phenocopy, and genetic heterogeneity. Genet Epidemiol. 2003;24(2):150-157.

37. Heiskanen JT, Pirskanen MM, Hiltunen MJ, et al. Insertion-deletion polymorphism in the gene for angiotensin-converting enzyme is associated with obstetric cholestasis but now with preeclampsia. Am J Obstet Gynecol. 2001;185(3):600-603.

38. Bouba I, Makrydimas G, Kalaitzidis R, et al. Interaction between the polymorphisms of the renin-angiotensin system in preeclampsia. Eur $J$ Obstet Gynecol Reprod Biol. 2003;110(1):8-11.
39. Roberts CB, Rom L, Moodley J, et al. Hypertension-related gene polymorphisms in pre-eclampsia, eclampsia and gestational hypertension in Black South African women. J Hypertens. 2004;22(5):945-948.

40. Kim YJ, Park MH, Park HS, et al. Association of polymorphisms of the angiotensinogen M235 polymorphism and angiotensin converting enzyme intron 16 insertion/deletion polymorphism with preeclampsia in Korean women. Eur J Obstet Gynecol Reprod Biol. 2004;116(1):48-53.

41. El-Shafei SA, Zein El Din MH, Galal AF, et al. The association of angiotensinogen converting enzyme (ACE) insertion/deletion polymorphism with preeclamptic women in Alexandria - Egypt. The Egyptian Journal of Medical Human Genetics. 2007;8(1):57-68.

42. Velloso EP, Vieira R, Cabral AC, et al. Reduced plasma levels of angiotensin-(1-7) and renin activity in preeclamptic patients are associated with the angiotensin I converting enzyme deletion/deletion genotype. Braz J Med Biol Res. 2007;40(4):583-590.

43. Miskovic B, Sertic J, Stavljenic-Rukavina A, et al. Association of angiotensin-converting enzyme insertion-deletion polymorphism with preeclampsia. Coll Antropol. 2008;32(2):339-343.

44. Procopciuc LM, Caracostea G, Zaharie G, et al. Maternal/newborn genotype contribution of the renin-angiotensin system (Met235Thr, Thr174Met, I/D-ACE, A2350G-ACE, A1166C-AT2R1, C3123A-AT2R2, 83A/G-REN) to the risk of pre-eclampsia: a Romanian study. $J$ Renin Angiotensin Aldosterone Syst. 2011;12(4):539-548

45. Salimi S, Mokhtari M, Yaghmaei M, et al. Association of angiotensinconverting enzyme intron 16 insertion/deletion and angiotensin II type 1 receptor A1166C gene polymorphisms with preeclampsia in South East of Iran. J Biomed Biotechnol. 2011;941515.

46. Serrano NC, Diaz LA, Paez MC, et al. Angiotensin-converting enzyme I/D polymorphism and preeclampsia risk: evidence of small-study bias. PLoS Med. 2006;3(12):e520.

47. Pfab T, Stirnberg B, Sohn A, et al. Impact of maternal angiotensinogen M235T polymorphism and angiotensin-converting enzyme insertion/ deletion polymorphism on blood pressure, protein excretion and fetal outcome in pregnancy. J Hypertens. 2007;25(6):1255-1261.

48. Benedetto C, Marozio L, Ciccone G, et al. Synergistic effect of reninangiotensin system and nitric oxide synthase genes polymorphisms in preeclampsia. Acta Obstet Gynecol Scand. 2007;86(6):678-682. 